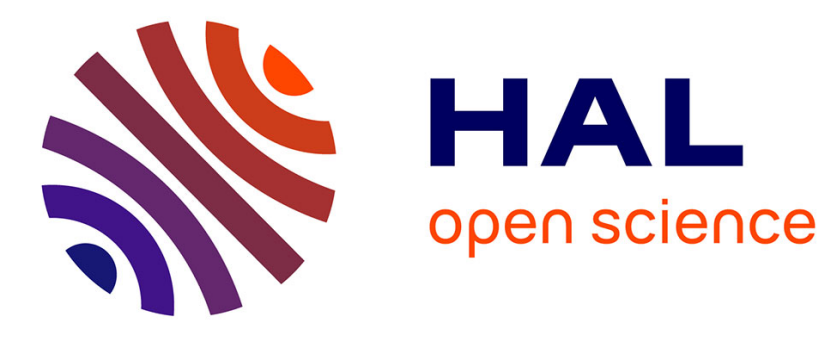

\title{
The usefulness of tandem accelerators as injectors to heavy ion boosters
}

\author{
K.H. Purser
}

\section{To cite this version:}

K.H. Purser. The usefulness of tandem accelerators as injectors to heavy ion boosters. Revue de Physique Appliquée, 1977, 12 (10), pp.1617-1621. 10.1051/rphysap:0197700120100161700 . jpa00244380

\section{HAL Id: jpa-00244380 https://hal.science/jpa-00244380}

Submitted on 1 Jan 1977

HAL is a multi-disciplinary open access archive for the deposit and dissemination of scientific research documents, whether they are published or not. The documents may come from teaching and research institutions in France or abroad, or from public or private research centers.
L'archive ouverte pluridisciplinaire HAL, est destinée au dépôt et à la diffusion de documents scientifiques de niveau recherche, publiés ou non, émanant des établissements d'enseignement et de recherche français ou étrangers, des laboratoires publics ou privés. 


\title{
THE USEFULNESS OF TANDEM ACCELERATORS AS INJECTORS TO HEAVY ION BOOSTERS
}

\author{
K. H. PURSER
}

General Ionex Corporation, 25, Hayward Street, Ipswich, Massachusetts 01938, U.S.A.

\begin{abstract}
Résumé. - Nous exposons les possibilités offertes par un accélérateur Tandem MP comme injecteur dans un post-accélérateur. Après avoir discuté les caractéristiques demandées nous concluons qu'un Tandem est bien adapté à cette tâche et surtout grâce aux possibilités des sources d'ions modernes.

Abstract. - We report about the possibilities of a Tandem MP accelerator as injector in a postaccelerator. After discussion of the required caracteristics we conclude that a Tandem is well suited for this work and this owing to the possibilities of modern ion sources.
\end{abstract}

During the past few years a variety of proposals have been made to construct machines that would accelerate a broad range of heavy ions to energies of several $\mathrm{MeV} /$ nucleon. Frequently, these proposals have included the use of a tandem accelerator to produce high charge low emittance beams which are then directed into the final stages of acceleration which might be a cyclotron or linac. An example of such a multiple accelerator system is that being proposed at the University of Rochester. This facility will use the existing MP Tandem to produce positive ions that would be injected into a superconducting heavy ion cyclotron.

Figure 1 is a calculation carried out by Elmore (1) which shows the energy/nucleon for particles as a function of mass for a tandem accelerating tube into a $500 \mathrm{MeV}$ superconducting cyclotron. The following assumptions are made in the calculation:

1. The negative ion current from the ion source is $10 \mu \mathrm{A}$.

2. The beam after pre-acceleration chopping is $2.5 \mu \mathrm{A}$.

3. The overall transmission through the accelerator, excluding charge exchange branching, is $50 \%$.

4. Terminal charge exchange will be in gas and the charge exchange branching is calculated according to the paper of Betz [1].

Calculations are shown for two terminal voltages, 11 and $12 \mathrm{MV}$. The lower voltage, an ultra-conservative rating, is shown because today the machine operates for days on end without any disruptions at this voltage. $12 \mathrm{MV}$ is shown as we expect equally reliable performance at this voltage with purified $\mathrm{SF}_{6}$.

Whenever predictions of the type shown in figure 1

(1) Elmore D. Private communication.

REVUE DE PHYSIQUE APPLIQUÉE. - T. 12, № 10, OCTOBRE 1977

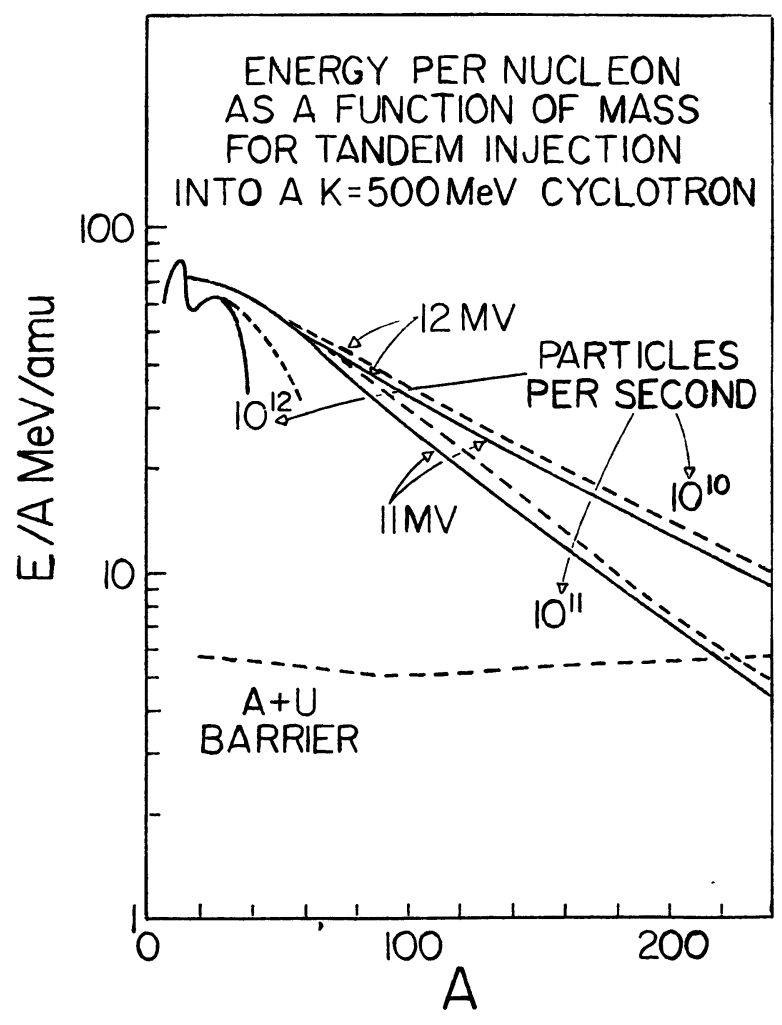

FIG. 1.

are made a series of questions arise in the mind of the reader about the basic suitability of a tandem as a booster injector.

1. Negative ions are not a usual state of matter. Can they be generated with sufficient intensity for most masses that the inevitable losses in the accelerator can be accepted? 
2. How serious are the losses from:

a. optical effects and lens aberrations?

b. charge exchange branching?

c. small angle scattering in the stripper?

d. vacuum conditions in the non-bakeable tubes?

3. Will the complex phenomenon of loading effectively prevent the acceleration of very high intensity beams?

4. Is charge state selection possible in existing machines to eliminate the need to accelerate unwanted positive ions?

5. Is the pulsed beam performance compatible with the injection requirements of a cyclotron?

6. Are tandems really reliable enough to be seriously considered as a positive ion source for a regional facility where predictable operations and the reliability of scheduling is absolutely essential to a successful laboratory?

I do not intend to address question 1 . because Middleton has covered this point thoroughly previously [2]. Answers to the other questions can be given by describing some measurements that have been made at Rochester and Oxford.

1. Experimental data on transmission. - Measurements have been made at Rochester on the transmission efficiency of the MP tandem using $150 \mathrm{keV}$ injection and beams of ${ }^{32} \mathrm{~S},{ }^{58 \mathrm{Ni}},{ }^{197} \mathrm{Au}$ from a refocused Middleton sputter source and ${ }^{16} \mathrm{O}$ from a duoplasmatron. I should point out that the Rochester tandem has several features that make it somewhat unique [3]. For the present measurements the most important features were the high capacity cryogenic terminal pumping and the non-aberrating spirally inclined field tubes.

Data was obtained which measured the intensity of individual charge states in a $M E / Q^{2}=300 \mathrm{amu}-\mathrm{MeV}$ magnet system for terminal voltages between 8 and 10.5 MV. The upper limit to the voltage was set by the fact that the accelerator had been open only a few hours previously and had not been conditioned. The analyzed current was normalized to an equivalent particle current, corrected for known losses (due to a gridded lens), and compared to the particle currents that should be observed assuming $100 \%$ transmission and the charge exchange branching of Betz [1].

Tables I to IV show the data for $V_{\mathrm{T}}=8 \mathrm{MV}$. For ${ }^{197} \mathrm{Au}$ it can be seen that currents of $\sim 2 \mu \mathrm{A}$ were injected and that the transmission efficiency was. between $25-30 \%$. Further measurements at the same energy where $4 \mu \mathrm{A}$ was injected gave essentially the same transmission efficiency. At no time was there any evidence of loading phenomena and we believe that significantly higher currents could have been injected. Within the error of the measurements there was no indication that the theoretical charge state distribu- tion had been distorted by stripping in the high energy tube. Such stripping would tend to remove low charge state components. Conversely, there was no indication of losses of high charge state components which would indicate small angle scattering effects. The data, which was taken at fixed stripper gas pressure, is consistent with the higher charge states being in equilibrium.

Figure 2 shows a graph of all the data. It can be seen that the transmission varies from close to $100 \%$ for $16 \mathrm{O}$ to $25-30 \%$ for ${ }^{197} \mathrm{Au}$. The line that has been drawn through the data is consistent with vacuum losses of negative ions in the low energy tubes dominating the transmission. It is important to put this piece of information in perspective. It indicates that a rather modest decrease in vacuum pressure is all that is needed to improve the transmission so that it is constant at $\sim 100 \%$ over the whole periodic table. One single pump located in the middle dead section of the accelerator will provide a pressure/length product reduction of four. Such an addition is planned and is technically a comparatively trivial addition.

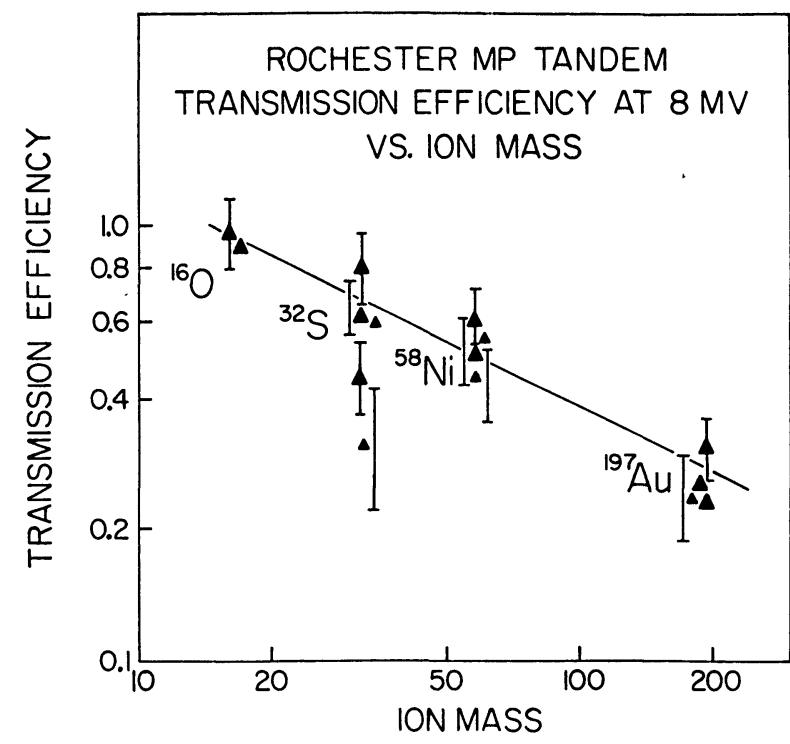

Fig. 2.

Table V shows transmission data at $10 \mathrm{MV}$. Here currents of $3 \mu \mathrm{A}$ of ${ }^{197} \mathrm{Au}$ were injected into the machine. The same treatment of data was used to calculate transmission efficiency. It can be seen that the measured efficiency is at least $50 \%$ of the theoretical maximum. Once again the machine showed no indications of loading phenomena. While the previous data at $8 \mathrm{MV}$ was encouraging the data at $10 \mathrm{MV}$ was conclusive; it is now possible to reliably predict that the injector accelerator is capable of handling currents that will result in $10^{11}$ particles per second from a superconducting cyclotron. With modest improvements in vacuum, injection optics, and charge state selection; $10^{12}$ particles per second appear quite reasonable as upper current limits. 
TABLE I

${ }^{16}$ Oxygen at $8 \mathrm{MV}$

\begin{tabular}{|c|c|c|c|c|c|c|}
\hline $\begin{array}{c}\text { Charge } \\
\text { state } \\
Q^{+}\end{array}$ & $\begin{array}{c}\text { Injected } \\
\text { current } \\
I_{L E}(\mu \mathrm{A})\end{array}$ & $\begin{array}{c}\text { Analyzed } \\
\text { current } \\
I_{0^{+}}(\mu \mathrm{A})\end{array}$ & $\begin{array}{c}\text { Particle } \\
\text { ratio }\end{array}$ & $\begin{array}{l}\text { Predicted } \\
\text { ratio }\end{array}$ & $\begin{array}{l}\text { Predicted } \\
\text { ratio after } \\
\text { allowance } \\
\text { for grid }\end{array}$ & $\begin{array}{c}\text { Transmission } \\
\text { efficiency }\end{array}$ \\
\hline - & - & - & - & - & - & - \\
\hline+2 & .500 & .056 & .056 & .004 & .0036 & \\
\hline+3 & - & .275 & .183 & .101 & .091 & \\
\hline+4 & - & .740 & .370 & .461 & .415 & .892 \\
\hline+5 & - & .820 & .328 & .377 & .339 & .968 \\
\hline+6 & - & .260 & .087 & .056 & .050 & \\
\hline+7 & - & .004 & .001 & .002 & .0018 & \\
\hline
\end{tabular}

TABLE II

${ }^{32}$ Sulphur at $8 \mathrm{MV}$

\begin{tabular}{|c|c|c|c|c|c|c|}
\hline $\begin{array}{c}\text { Charge } \\
\text { state } \\
Q^{+}\end{array}$ & $\begin{array}{c}\text { Injected } \\
\text { current } \\
I_{\mathrm{LE}}(\mu \mathrm{A})\end{array}$ & $\begin{array}{c}\text { Analyzed } \\
\text { current } \\
I_{Q^{+}}(\mu \mathrm{A})\end{array}$ & $\begin{array}{c}\text { Particle } \\
\text { ratio }\end{array}$ & $\begin{array}{l}\text { Predicted } \\
\text { ratio }\end{array}$ & $\begin{array}{l}\text { ratio after } \\
\text { allowance } \\
\text { for grid }\end{array}$ & $\begin{array}{l}\text { Transmission } \\
\text { efficiency }\end{array}$ \\
\hline- & $\overline{80}$ & $\overline{6}$ & $\overline{1438}$ & $\overline{2011}$ & $\overline{1810}$ & $\overline{704}$ \\
\hline+4 & 8.0 & 4.6 & . 1438 & 2011 & . 1810 & .794 \\
\hline+5 & 6.2 & 6.2 & .2000 & .3637 & .3273 & .611 \\
\hline+6 & 6.2 & 4.0 & . 1875 & 2790 & 2511 & .747 \\
\hline+7 & 6.1 & 1.1 & .0258 & .0908 & .0817 & .316 \\
\hline+8 & 6.0 & .32 & .0067 & .0125 & .0113 & .593 \\
\hline+9 & 7.8 & .085 & .0012 & .0007 & .0006 & - \\
\hline
\end{tabular}

TABLE III

${ }^{58}$ Nickel at $8 \mathrm{MV}$

\begin{tabular}{|c|c|c|c|c|c|c|}
\hline $\begin{array}{c}\text { Charge } \\
\text { state } \\
Q^{+}\end{array}$ & $\begin{array}{c}\text { Injected } \\
\text { current } \\
I_{\mathrm{LE}}(\mu \mathrm{A})\end{array}$ & $\begin{array}{c}\text { Analyzed } \\
\text { current } \\
I_{O^{+}}(\mu \mathrm{A})\end{array}$ & $\begin{array}{c}\text { Particle } \\
\text { ratio }\end{array}$ & $\begin{array}{l}\text { Predicted } \\
\text { ratio }\end{array}$ & $\begin{array}{l}\text { Predicted } \\
\text { ratio after } \\
\text { allowance } \\
\text { for grid }\end{array}$ & $\begin{array}{c}\text { Transmission } \\
\text { efficiency }\end{array}$ \\
\hline - & - & - & - & - & - & - \\
\hline+4 & .600 & .300 & .125 & .2269 & .2042 & .622 \\
\hline+5 & .700 & .460 & .131 & .2788 & .2509 & .522 \\
\hline+6 & .700 & .360 & .0857 & .2099 & .1889 & .454 \\
\hline+7 & .650 & .220 & .0483 & .0968 & .0871 & .555 \\
\hline+8 & .650 & .130 & .0230 & .0274 & .0247 & .931 \\
\hline
\end{tabular}

TABLE IV

${ }^{197}$ Gold at $8 \mathrm{MV}$

\begin{tabular}{|c|c|c|c|c|c|c|}
\hline $\begin{array}{c}\text { Charge } \\
\text { state } \\
Q^{+}\end{array}$ & $\begin{array}{c}\text { Injected } \\
\text { current } \\
I_{\mathrm{LE}}(\mu \mathrm{A})\end{array}$ & $\begin{array}{c}\text { Analyzed } \\
\text { current } \\
I_{Q^{+}}(\mu \mathrm{A})\end{array}$ & $\begin{array}{l}\text { Particle } \\
\text { ratio }\end{array}$ & $\begin{array}{l}\text { Predicted } \\
\text { ratio }\end{array}$ & $\begin{array}{l}\text { Predicted } \\
\text { ratio after } \\
\text { allowance } \\
\text { for grid }\end{array}$ & $\begin{array}{l}\text { Transmission } \\
\text { efficiency }\end{array}$ \\
\hline+6 & $\overline{1.80}$ & $\overline{.300}$ &.$\overline{0277}$ &.$\overline{1346}$ & $\overline{.1214}$ & $\overline{228}$ \\
\hline+7 & 2.30 & .380 & .0236 & .0840 & .0756 & .312 \\
\hline+8 & 2.20 & .175 & .0099 & .0424 & .0382 & .259 \\
\hline+9 & 2.17 & .070 & .00358 & .0173 & .0156 & .229 \\
\hline+10 & 2.05 & .020 & .00097 & .0057 & .0051 & .190 \\
\hline+11 & 1.90 & .005 & .00024 & .0015 & .0013 & .185 \\
\hline \multicolumn{7}{|c|}{ ADDITIONAL DATA WITH THE DEFINING APERTURE REMOVED } \\
\hline+7 & 4.00 & .600 & .0214 & .0846 & .0756 & .283 \\
\hline
\end{tabular}


TABLE V

${ }^{197}$ Gold at $10 \mathrm{MV}$

\begin{tabular}{|c|c|c|c|c|c|c|}
\hline $\begin{array}{c}\text { Charge } \\
\text { state } \\
Q^{+}\end{array}$ & $\begin{array}{c}\text { Injected } \\
\text { current } \\
I_{\mathrm{LE}}(\mu \mathrm{A})\end{array}$ & $\begin{array}{c}\text { Analyzed } \\
\text { current } \\
I_{Q^{+}}(\mu \mathrm{A})\end{array}$ & $\begin{array}{c}\text { Particle } \\
\text { ratio }\end{array}$ & $\begin{array}{l}\text { Predicted } \\
\text { ratio }\end{array}$ & $\begin{array}{l}\text { Predicted } \\
\text { ratio after } \\
\text { allowance } \\
\text { for grid }\end{array}$ & $\begin{array}{c}\text { Transmission } \\
\text { efficiency }\end{array}$ \\
\hline- & - & - & - & - & - & - \\
\hline+8 & 3.10 & .950 & .0383 & .0639 & .0575 & .666 \\
\hline+9 & 3.02 & .350 & .0129 & .0308 & .0277 & .466 \\
\hline+10 & 3.00 & .170 & .0057 & .0122 & .0110 & .515 \\
\hline+11 & 3.10 & .072 & .0021 & .0040 & .0036 & .586 \\
\hline
\end{tabular}

2. Confirming measurements. - Confirming measurements on transmission properties of the EN tandem at Oxford have been supplied by Hyder ( ${ }^{2}$ ). Oxford University has experience in the injection of medium mass ions into a similar spirally inclined acceleration structure. No significant loading has been observed for the following beams:

$\begin{array}{cccc}\text { Ion } & \begin{array}{c}\text { Current } \\ \text { Injected }\end{array} & \begin{array}{c}\text { Voltage } \\ -\end{array} & \begin{array}{c}\text { Equiv. MP } \\ \text { Voltage }\end{array} \\ 12 \mathrm{C} & 17 \mu \mathrm{A} & 4 \mathrm{MV} & 8 \overline{\mathrm{MV}} \\ 16 \mathrm{O} & 5 \mu \mathrm{A} & 5.5 \mathrm{MV} & 11 \mathrm{MV} \\ 19 \mathrm{~F} & 8 \mu \mathrm{A} & 6 \mathrm{MV} & 12 \mathrm{MV} \\ 32 \mathrm{~S} & 6 \mu \mathrm{A} & 6 \mathrm{MV} & 12 \mathrm{MV} \\ 127 \mathrm{I} & 2 \mu \mathrm{A} & 6.2 \mathrm{MV} & 12.4 \mathrm{MV}\end{array}$

Transmission data for ions through the Oxford tandem are consistent with the $\mathrm{U}$ of $\mathrm{R}$ measurements:

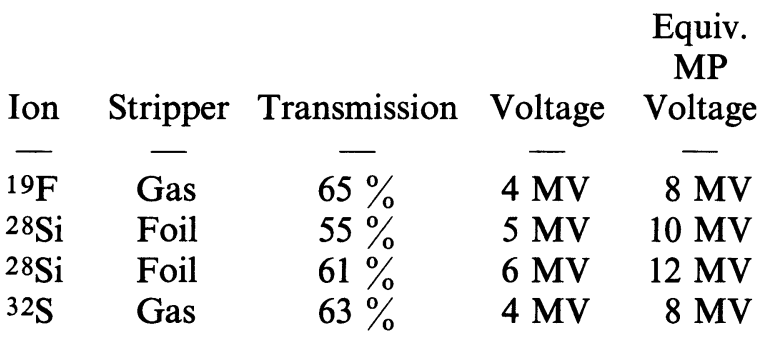

3. Small angle scattering. - Recent work of Hooton, Freeman and Kane [4], at AERE Harwell, on the scattering of heavy ions shows that the half angles introduced into the beam by multiple scattering are much less than those computed on the basis of the theory of Nigam, Sundareson and Wu [5]. Thus, transmission of multiply stripped heavy ion beams through tandem tubes is higher than some recent calculations have suggested.

4. Pulsing. - Nanosecond beam pulsing is an integral part of most booster proposals. For example, the superconducting cyclotron has rf frequencies that will lie between 27-84 MHz. The phase angle of acceptance will be approximately $15^{\circ}$ for maximum intensity or $2^{\circ}$ for best resolution. These specifications

(2) Hyder R. McK. Private communication. translate into beam bursts with width and phase stability $\sim 0.2 \mathrm{~ns}$. Figure 3 shows the pulse beam performance of the Rochester tandem during ${ }^{3} \mathrm{He}$ pulsing.

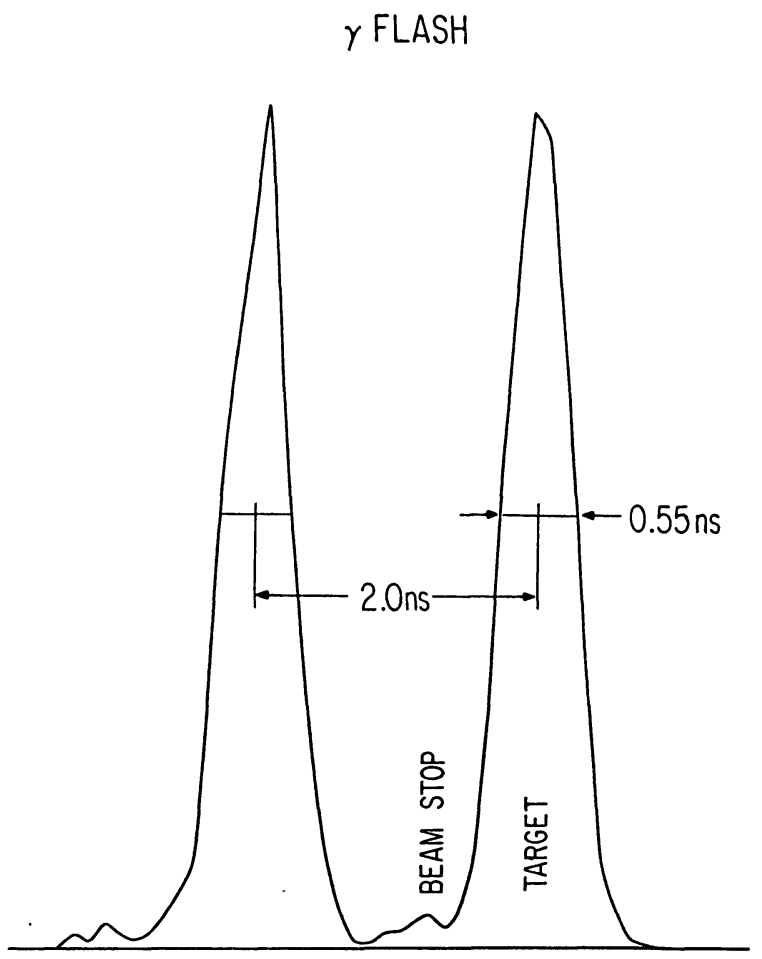

FIG. 3.

In practice the timing specifications of the previous paragraph are probably impossible to meet if all of the beam pulsing is done before the tandem accelerator. A touch-up buncher will be needed following the accelerator. The reason why bunching must be done after the machine is that small changes in the tandem terminal voltage, or the voltage gradients, produce significant variations in the transit time of ions through the machine compared to $1 \mathrm{~ns}$. A very sensitive region is the injector drift spaces between the buncher and the machine; here the velocity of the particles is slow and the transit times long. For example, $\mathrm{I}^{-}$particles injected at $2 \mathrm{MeV}$ with an energy stability of $\pm 0.5 \mathrm{keV}$ have time fluctuations at the target of \pm 1.3 ns. Terminal fluctuations are less 
critical but they must still be kept within a few $\mathrm{kV}$. This is well within the normal operating range of an MP tandem at $11 \mathrm{MV}$.

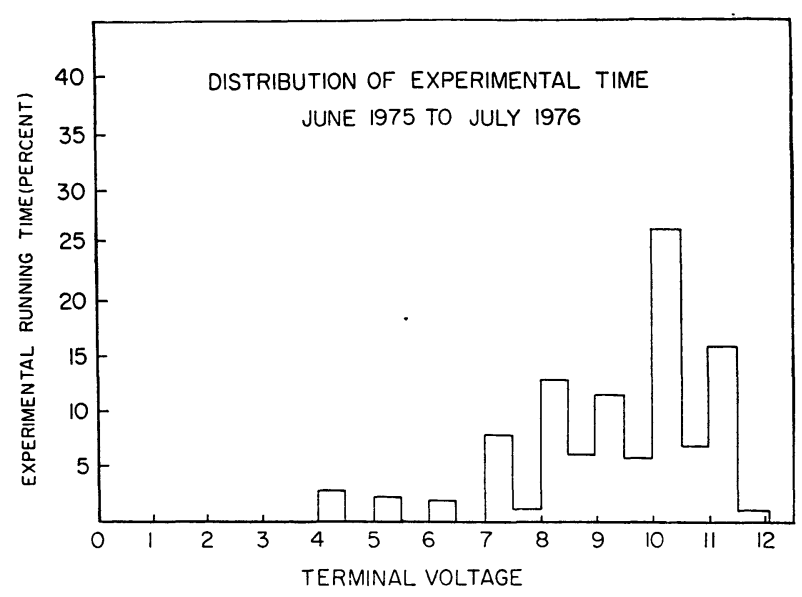

Fig. 4.

It is important that the value of $\mathrm{d} E / \mathrm{d} t$, the rate of change of beam energy following the modulation, be moderately large for all ion species. Firstly, $\mathrm{d} E / \mathrm{d} t$ $\times \Delta t$, where $\Delta t$ is the desired time resolution, should be much larger than the natural energy spreads that are present in the ions leaving the source. Secondly, and in practice more important, is that $\mathrm{d} E / \mathrm{d} t \times \Delta t$ should be large compared to fast power supply fluctuations in the injector. High frequency ripples and fast voltage fluctuations of the order of hundreds of volts are common in existing injector systems and in practice are difficult to avoid. A practical solution which will operate reliably is to keep $E$ and $\mathrm{d} E / \mathrm{d} t$ high. There are other reasons for injecting at high energies one of which is that ions which travel along the axis have a slightly different time history than ions which travel at the edges of the tube. While all particles have received the same energy by the time that they reach the terminal, the time history of the extremum rays is different. At injection energies of hundreds of kilovolts these effects can be important if a focus is not located at the entrance to the first acceleration tube. They become of little consequence
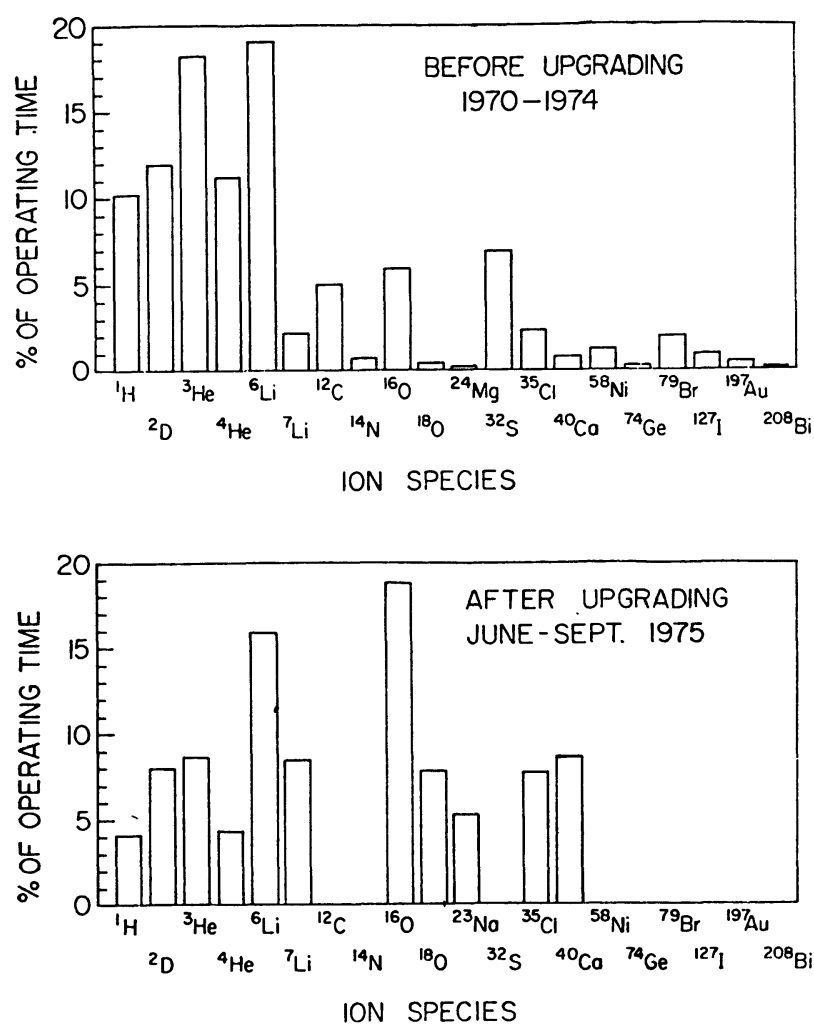

FIG. 5.

at injection energies of $2 \mathrm{MeV}$ even when conventional optics are used.

Figure 4 shows the high voltage performance of the Rochester MP tandem for experimental measurements. It should be emphasized that experimental programs are not commenced until long term realiability is assured at a particular level. It can be seen that $11 \mathrm{MV}$ is a conservative rating. Figure 5 shows the range of heavy ions that have already been used in experimental programs at Rochester.

5. Summary. - When we examine the questions posed at the beginning of this talk we believe that in no case is the tandem excluded as a suitably heavy ion injector. Rather, the reliability and flexibility of modern ion sources make it an almost ideal machine for booster injection.

\section{References}

[1] Betz, H. D., Rev. Mod. Phys. 44 (1972) 460.

[2] Middleton, R., Nucl. Instrum. Methods 122 (1974) 35.

[3] Purser, K. H., et al, Nucl. Instrum. Methods 122 (1974) 159.

[4] Hooten, B. W., Freeman, J. M. and Kane, P. P., Nucl. Instrum. Methods 124 (1975) 29.

[5] Nigam, B. P., Sundareson, M. K. and Wu, T. Y., Phys. Rev. 115 (1959) 491. 